CZASOPISMO INŻYNIERII LA¿OWEJ, ŚRODOWISKA I ARCHITEKTURY JOURNAL OF CIVIL ENGINEERING, ENVIRONMENT AND ARCHITECTURE

JCEEA, t. XXXIV, z. 64 (3/I/17), lipiec-wrzesień 2017, s. 293-305, DOI: 10.7862/rb.2017.123

\author{
Michał GOŁDYN ${ }^{1}$ \\ Lukasz KRAWCZYK ${ }^{2}$ \\ Tadeusz URBAN ${ }^{3}$
}

\title{
PRZYCZYNEK DO ROZWAŻAŃ NA TEMAT NOŚNOŚCI ELEMENTÓW Z UWAGI NA PRZECINANIE BETONU
}

\begin{abstract}
$\mathrm{W}$ artykule przedstawiono zagadnienie nośności betonu $\mathrm{w}$ elemencie $\mathrm{z}$ uwagi na przecinanie. Rozważano modele ze „stykami” zbrojonymi i niezbrojonymi. Stwierdzono, iż wprowadzenie zbrojenia poprzecznego do hipotetycznej powierzchni zniszczenia umożliwia zmianę mechanizmu zniszczenia z kruchego na ciągliwe, czemu towarzyszy wyraźny wzrost nośności - w rozważanych badaniach dochodził on do $80 \%$ w odniesieniu do elementu ze stykiem niezbrojonym. Dokonano porównania wyników badań eksperymentalnych w świetle procedur obliczeniowych Eurokodu 2 i Model Code 2010, odnoszących się do naprężeń granicznych w styku pomiędzy betonami układanymi w różnym czasie. Okazały się bardzo zachowawcze w stosunku do styków w pełni monolitycznych. Procedury normowe zaniżyły wpływ sił przyczepności (adhezji) i zazębiania kruszywa w odniesieniu do elementów wykonanych z tego samego betonu. Skutkiem tego nośności eksperymentalne były nawet 3,5 - krotnie wyższe od wartości ustalonych zgodnie z procedurami normowymi. Dzięki zastosowaniu aparatu do pomiarów optycznych ARAMIS, możliwa była dokładna analiza odkształceń ciał próbnych i określenie granicznych przemieszczeń krawędzi styku.
\end{abstract}

Słowa kluczowe: przecinanie, styk beton - beton, naprężenia styczne, zazębianie kruszywa, efekt dyblujący, cyfrowa korelacja obrazów

\section{Wstęp}

Problem przecinania betonu zauważalny jest szczególnie w przypadku bardzo krótkich wsporników, gdy smukłość ścinania $\lambda=a_{c} / h$ nie przekracza 0,3 (gdzie $a_{c}$ stanowi odległość punktu przyłożenia obciążenia od krawędzi słupa, zaś $h$ wysokość wspornika). Zagadnienie to zostało przemilczane w Eurokodzie 2 [3]. Zamieszczona tam procedura obliczeniowa pozwala na wymiarowanie wsporników

\footnotetext{
${ }^{1}$ Autor do korespondencji / corresponding author: Michał Gołdyn, Politechnika Łódzka, Katedra Budownictwa Betonowego, al. Politechniki 6, 90-924 Łódź, tel. (42) 631-35-80, e-mail: michal.goldyn@p.lodz.pl

${ }^{2}$ Łukasz Krawczyk, Politechnika Łódzka, Katedra Budownictwa Betonowego

${ }^{3}$ Tadeusz Urban, Politechnika Łódzka, Katedra Budownictwa Betonowego
} 
krótkich, gdy kąt nachylenia teoretycznego krzyżulca ściskanego modelu S-T $\theta$ wynosi $45^{\circ} \div 68^{\circ}$, co w praktyce oznacza $\lambda>0,3$. W przypadku analizy elementów o innym kształcie konieczne jest stosowanie odmiennych reguł - na przykład zasad normy amerykańskiej ACI 318-14 [1]. Opisana w niej procedura, dotycząca bardzo krótkich wsporników, bazuje na mechanizmie ścinanie - tarcie (shear friction). Jak pokazały jednak wyniki obliczeń wykonanych w ramach badań własnych, opisanych w [6], metoda ta prowadzi do znacznego niedoszacowania nośności bardzo krótkich wsporników. Dotychczasowe badania eksperymentalne (przedstawione m.in. w [4] i [5]), dotyczące zagadnienia nośności, odnosiły się do styków pomiędzy betonami układanymi $\mathrm{w}$ różnym czasie. Jak pokazały wyniki tych rozważań, graniczne naprężenia styczne $v_{R d, i}$ są w dużej mierze zależne od sposobu przygotowania powierzchni - jej szorstkości i czystości. Takowy problem nie występuje w przypadku elementów wykonywanych w tym samym czasie. Należało wobec tego oczekiwać, iż zalecenia sformułowane przez Randla i Wicke w [5], uwzględnione następnie w procedurze Model Code 2010 [2], będą zachowawcze $\mathrm{w}$ stosunku do przecinania $\mathrm{w}$ elementach $\mathrm{w}$ pełni zmonolityzowanych. W celu jakościowej oceny tego zagadnienia w Katedrze Budownictwa Betonowego zainicjowano badania pilotażowe, w których rozważano przecinanie, określane dalej jako ścinanie w ,styku” betonów ułożonych w tym samym czasie. Badania te miały również na celu sprawdzenie możliwości nowo zakupionego urządzenia ARAMIS, służącego do pomiarów optycznych.

\section{Badania własne}

Seria próbna składała się z trzech elementów, w kształcie litery Z, wykonanych $\mathrm{w}$ całości $\mathrm{z}$ tego samego betonu. Zbrojenie modeli badawczych pokazano na rys. 1 . Jedyny parametr zmienny stanowił stopień zbrojenia poprzecznego do powierzchni styku $\left(\rho_{s}\right)$, równy $0,0 \%, 0,59 \%$ oraz $0,92 \%$.
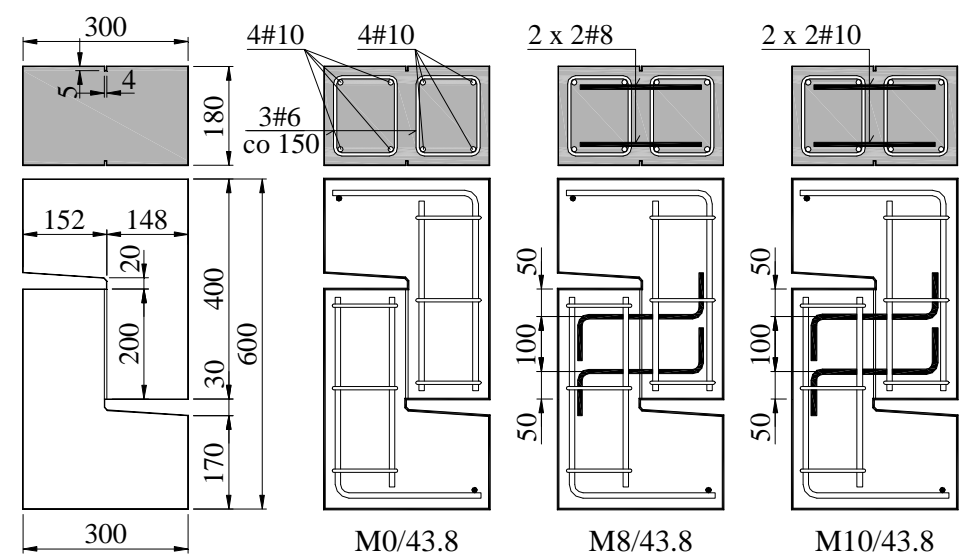

Rys. 1. Wymiary, kształt i zbrojenie badanych elementów

Fig. 1. Dimensions, shape and reinforcement of test specimens 
Zbrojenie poprzeczne składało się z czterech prętów $\varnothing 8(\mathrm{M}$ - 8/43.8) lub $\varnothing 10(\mathrm{M}-10 / 43.8)$. Wytrzymałość betonu na ściskanie $f_{c m}$ i rozciąganie (przez rozłupywanie) $f_{s p}$ określono w dniu badania na próbkach walcowych i kostkowych. Była ona równa odpowiednio $f_{c m}=43,8 \mathrm{MPa}$ oraz $f_{s p}=3,65 \mathrm{MPa}$.

Badania prowadzono $\mathrm{w}$ prasie o maksymalnym nacisku $6000 \mathrm{kN}$ (patrz rys. 2.). Przebieg procesu obciążania rejestrowano za pomocą urządzenia do pomiarów optycznych ARAMIS, zapisując 10 klatek na sekundę. W początkowej fazie siłę zwiększano skokowo co około $30 \mathrm{kN}$. Przy większym zaawansowaniu obciążenia (około $60 \div 70 \%$ siły niszczącej) rozpoczynano zwiększanie siły w sposób ciągły.

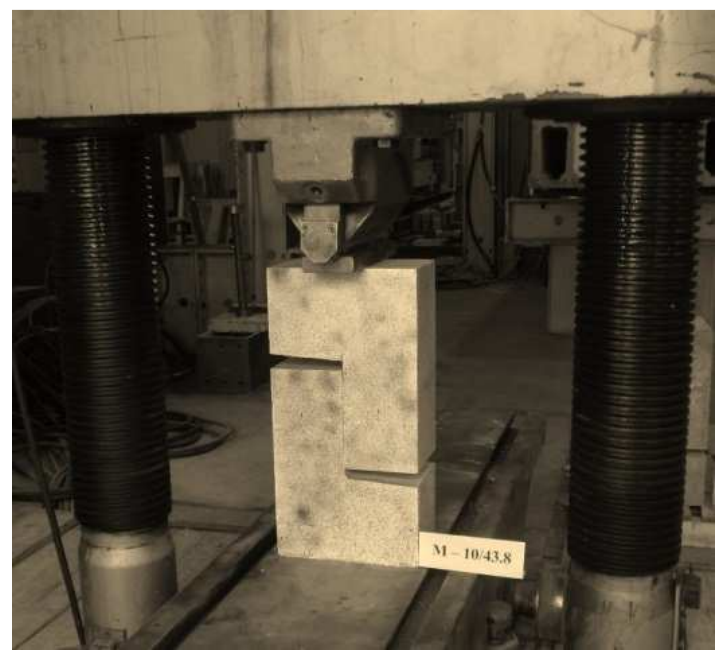

Rys. 2. Widok stanowiska badawczego

Fig. 2. Test setup - front view

\section{Wyniki badań}

Zniszczenie modelu M - 0/43.8 ze stykiem niezbrojonym miało charakter gwałtowny. Rozszczepienie elementu nastąpiło w czasie krótszym niż $0,1 \mathrm{~s}$ co można było stwierdzić analizując obrazy zarejestrowane w trakcie badania patrz rys. 3. Wobec braku zbrojenia poprzecznego zniszczenie nie było wcześniej sygnalizowane w postaci zarysowania w obrębie styku.

Analiza obrazów zarejestrowanych za pomocą kamer systemu ARAMIS umożliwiła jakościową ocenę rozkładu sił wewnętrznych w elemencie. Na podstawie map odkształceń $\varepsilon_{x}$ (w kierunku pionowym) można było stwierdzić silną koncentrację naprężeń na końcach styku (obszary oznaczone na rys. 4.). Rozpatrując mapy odkształceń poziomych $\varepsilon_{y}$ można zauważyć, iż zniszczenie styku zostało zainicjowane w górnej jego części. Przejawiało się ono powstaniem rysy bezpośrednio przed zniszczeniem, na co wskazywała kumulacja odkształceń widoczna na rys. 4. 


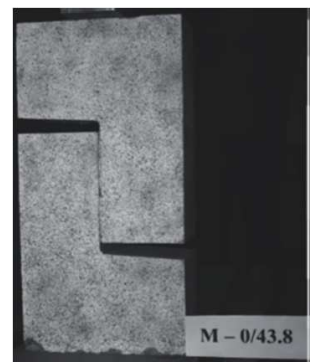

$0,0 \mathrm{~s}$

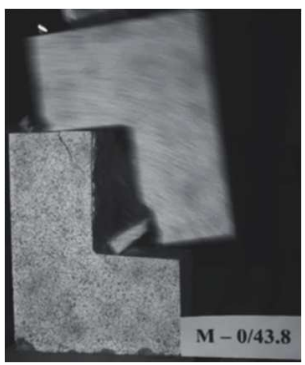

$0,1 \mathrm{~s}$

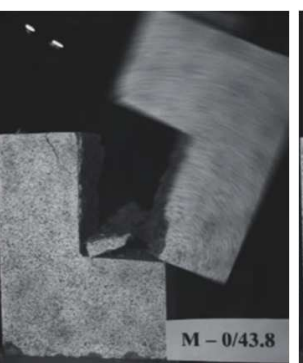

$0,2 \mathrm{~s}$

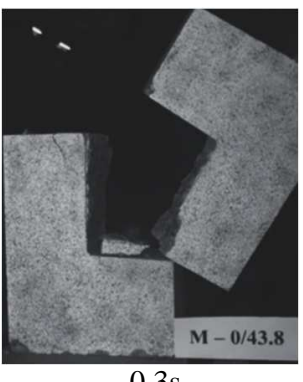

$0,3 \mathrm{~s}$

Rys. 3. Przebieg niszczenia modelu $\mathrm{M}-0 / 43.8$

Fig. 3. Course of destruction of $\mathrm{M}-0 / 43.8$ specimen
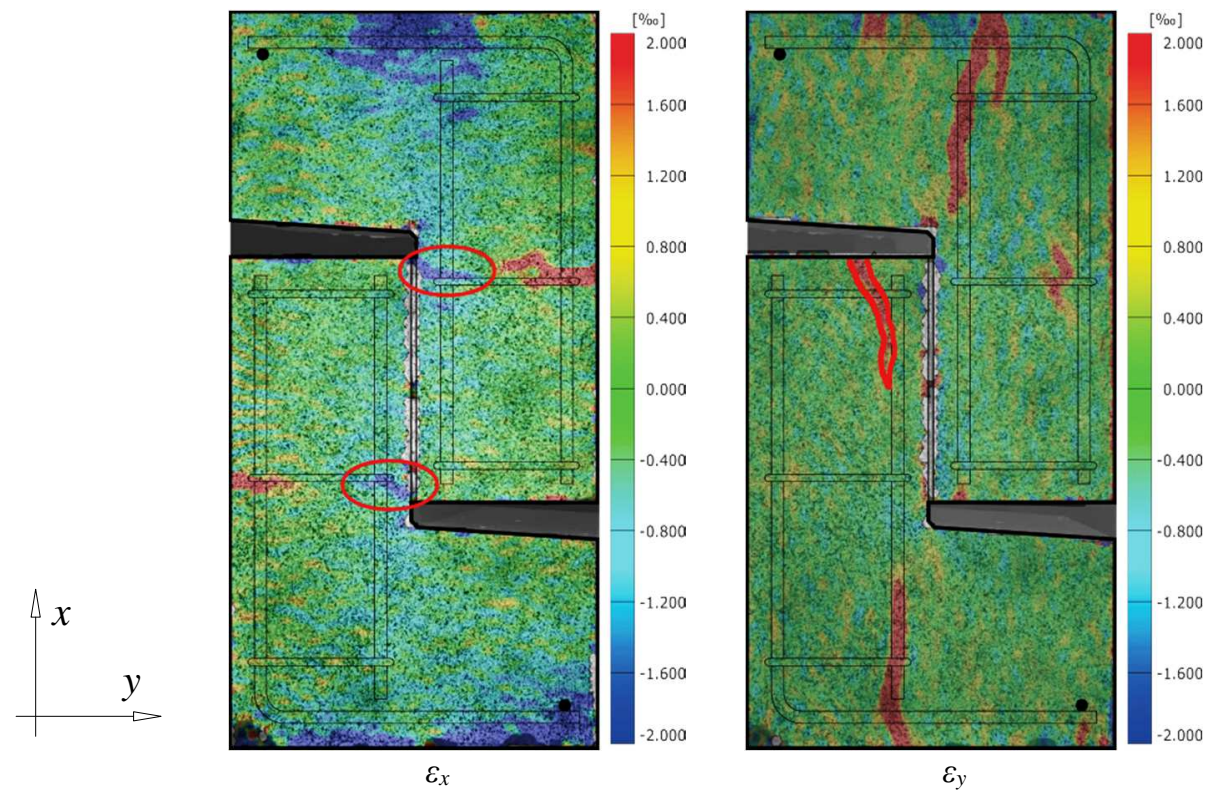

Rys. 4. Odkształcenia powierzchni modelu $\mathrm{M}-0 / 43.8$ bezpośrednio przed zniszczeniem

Fig. 4. Strains on surface of $M-0 / 43.8$ immediately before failure

Analizując mapy odkształceń powierzchni pozostałych dwóch modeli ze stykami zbrojonymi, wykonane w chwili poprzedzającej zniszczenie, można zauważyć wyraźnie zaakcentowany przebieg naprężeń ściskających - patrz rys. 5-6. $\mathrm{W}$ połowie wysokości styku przechodzą one $\mathrm{z}$ jednej części elementu na drugą. Towarzyszą temu siły rozszczepiające, widoczne szczególnie dobrze na mapach odkształceń poziomych $\varepsilon_{y}$, sporządzonych w przypadku modelu $\mathrm{M}-8 / 43.8$. Deformacja (przeginanie) i wyciąganie zbrojenia poprzecznego wywołały naprężenia rozciągające $\sigma_{x}$ przy końcach styku, w poziomie zbrojenia poprzecznego. 

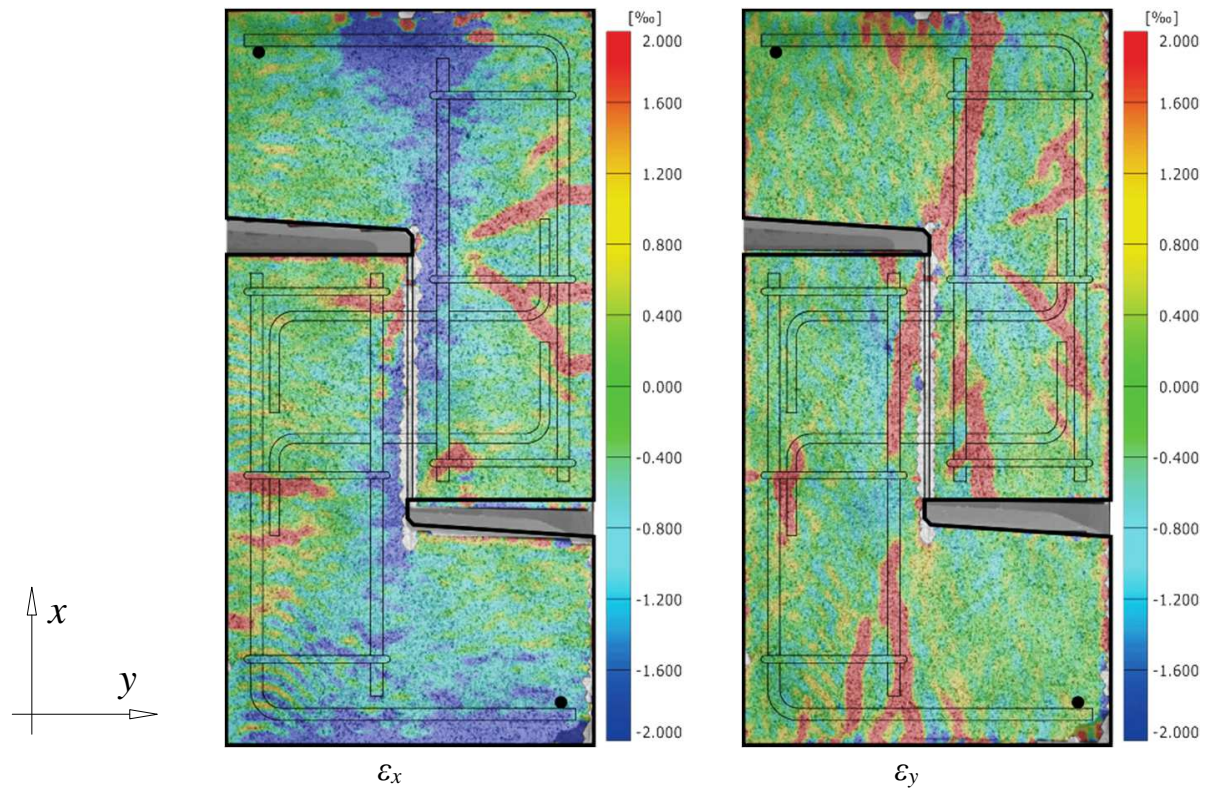

Rys. 5. Odkształcenia powierzchni modelu $\mathrm{M}-8 / 43.8$ bezpośrednio przed zniszczeniem Fig. 5. Strains on surface of $M-8 / 43.8$ immediately before failure
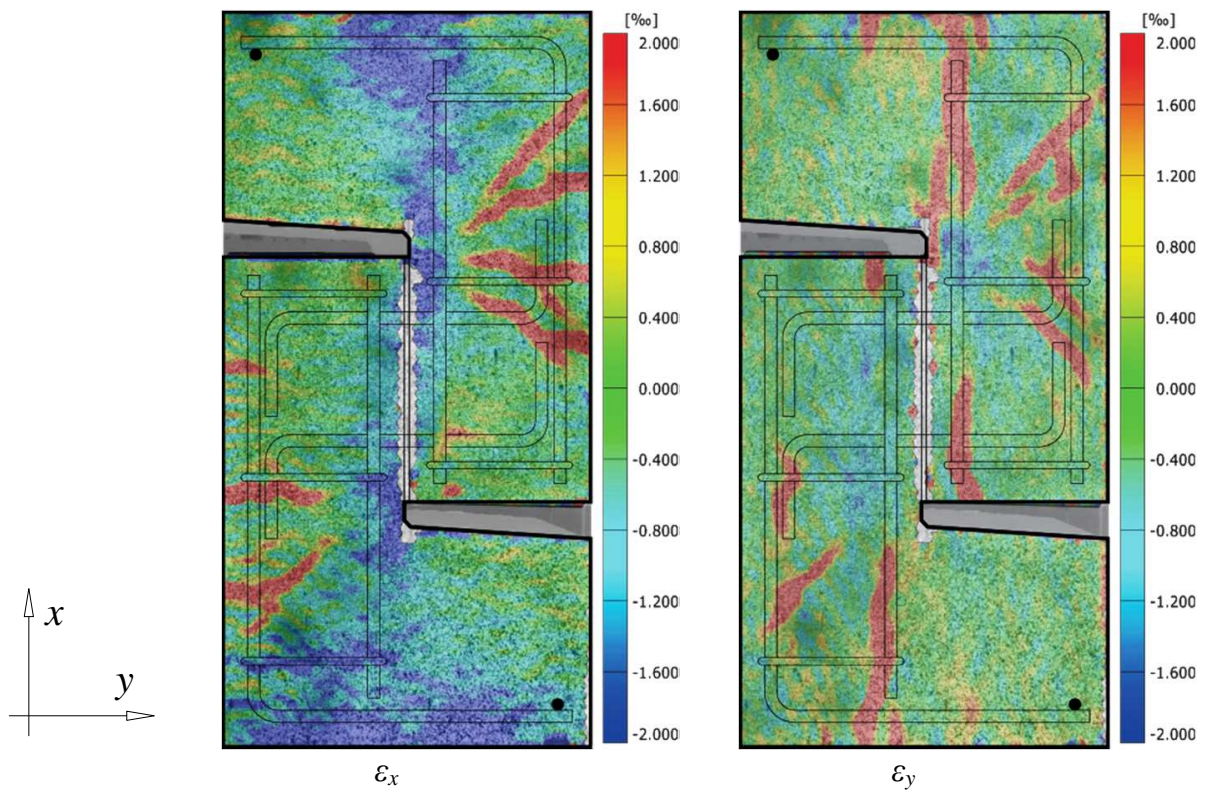

Rys. 6. Odkształcenia powierzchni modelu $\mathrm{M}-8 / 43.8$ bezpośrednio przed zniszczeniem

Fig. 6. Strains on surface of $M-8 / 43.8$ immediately before failure 
Podobny obraz odkształceń obserwowano także w przypadku elementu M - 10/43.8 - patrz rys. 6 . Tu także wyraźne były poziome naprężenia rozciągające występujące przy krawędzi styku i związane $\mathrm{z}$ wyciąganiem zbrojenia poprzecznego. Rozpatrując rys. 5. i 6 . można zauważyć naprężenia rozciągające w obrębie haków prętów poprzecznych, świadczące o ich wyciąganiu.

$\mathrm{Z}$ uwagi na brak zbrojenia zszywającego a także nacisku poprzecznego do powierzchni styku, nośność modelu $\mathrm{M}-0 / 43.8$ zależna była wyłącznie od sił adhezji. Ich utrata była gwałtowna i nastąpiła przy wzajemnym przemieszczeniu obu części elementu badawczego o około $0,15 \mathrm{~mm}$. W przypadku badań Randla [5], dotyczących połączeń beton - nadbeton, maksymalne przemieszczenie krawędzi niezbrojonych styków o powierzchniach lekko uszorstnionych, przy którym dochodziło do zerwania wiązań adhezyjnych, wynosiło około $0,05 \mathrm{~mm}$. Było zatem znacznie mniejsze od zarejestrowanego przez autorów w trakcie badania elementu w pełni monolitycznego.

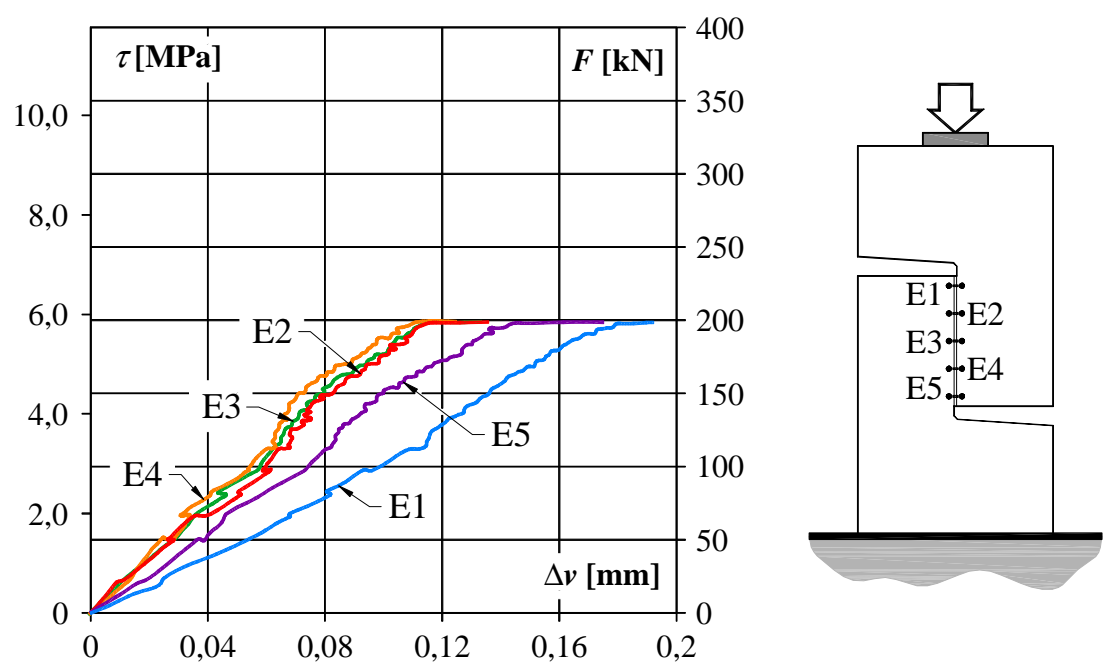

Rys. 7. Wzajemne przemieszczenie pionowe $\Delta v$ krawędzi styku elementu $\mathrm{M}-0 / 43.8$

Fig. 7. Vertical displacement $\Delta v$ between edges of the interface of $\mathrm{M}-0 / 43.8$ specimen

$\mathrm{Na}$ rysunku 7. pokazano przemieszczenia pomiędzy krawędziami styku modelu M - 0/43.8 w różnych poziomach. Można zauważyć różną intensywność narastania przemieszczeń. Większe rejestrowano w pobliżu końców styku w momencie zniszczenia wynosiły one $0,17 \div 0,19 \mathrm{~mm}$. W chwili poprzedzającej zniszczenie naprężenia styczne $\tau$ dochodziły niemal do $6 \mathrm{MPa}$ - a zatem wartości bliskiej wytrzymałości betonu przy przecinaniu, określonej według hipotezy Mohra: $\tau=0,5\left(f_{\mathrm{cm}} \cdot f_{c t m}\right)^{0,5}=0,5(43,8 \cdot 3,3)^{0,5}=6,01 \mathrm{MPa}$. Było to możliwe dzięki siłom adhezji działającym w zakresie bardzo małych przemieszczeń krawędzi styku. Powierzchnia powstała wskutek ścięcia betonu w styku charak- 
teryzowała się bardzo dużą szorstkością, co pokazano na rys. 11a. Na rysunku 8. porównano zależności $\tau-\Delta v$ (inaczej $F-\Delta v$ ) w odniesieniu do wszystkich badanych modeli. Zależności obciążenie - przemieszenie w przypadku modeli ze stykami zbrojonymi poprzecznie ma inny charakter. Wprowadzenie zbrojenia umożliwiło zmianę mechanizmu zniszczenia styku - z kruchego na ciągliwy. Wynika to z działania dwóch dodatkowych mechanizmów: zazębiania kruszywa (aggregate interlock) oraz efektu dyblowania (dowel action), które nie mogły zadziałać w przypadku styku niezbrojonego. W rezultacie rejestrowano znacznie większe obciążenia maksymalne, stanowiące $163 \%$ oraz $180 \%$ siły niszczącej model odniesienia $\mathrm{M}$ - 0/43.8 (odpowiednio w przypadku $\mathrm{M}$ - 8/43.8 i $\mathrm{M}$ 10/43.8). Efekt zazębiania kruszywa, możliwy dzięki krępowaniu styku poprzez zbrojenie poprzeczne, umożliwił uzyskanie większej siły niszczącej. Maksymalnemu obciążeniu towarzyszyły jednak znacznie większe przemieszczenia naprzeciwległych krawędzi styku, dochodzące do około $0,50 \mathrm{~mm}$. Były one zatem ponad trzykrotnie większe od rejestrowanych $\mathrm{w}$ chwili zniszczenia modelu $\mathrm{M}-0 / 43.8$ - patrz rys. 9 .

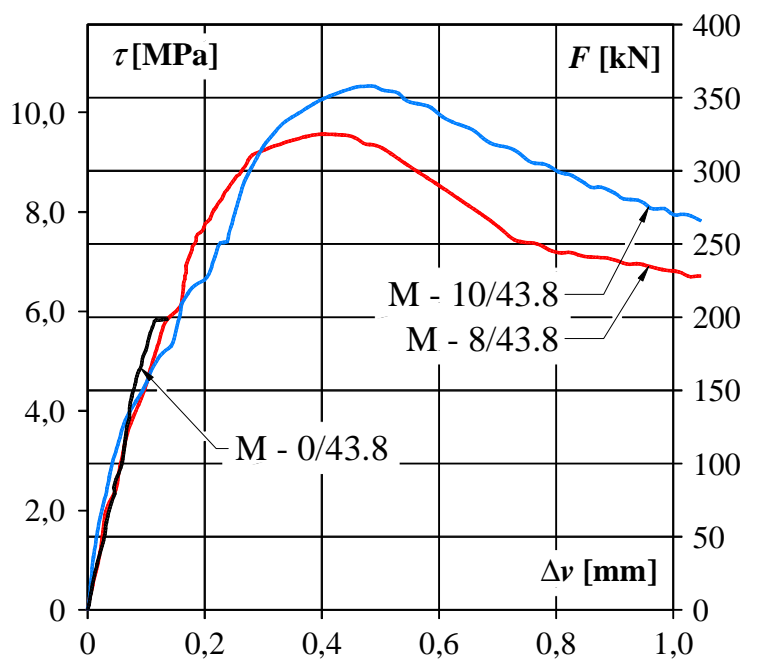

Rys. 8. Porównanie średnich przemieszczeń krawędzi styków badanych modeli

Fig. 8. Comparison of the mean displacements between edges of the interface

Zastosowanie urządzenia do pomiarów optycznych umożliwiło rejestrację deformacji modelu $\mathrm{M}-8 / 43.8$ także po przekroczeniu obciążenia maksymalnego. Widoczny jest stopniowy spadek siły i towarzyszące temu wzajemne przemieszczanie obu krawędzi styku. Na podstawie charakteru otrzymanego wykresu można wnosić, iż początek uplastycznienia zbrojenia poprzecznego nastąpił przy około $130 \mathrm{kN}$ ( 40\% obciążenia maksymalnego). W dalszym etapie obserwowano intensywny wzrost deformacji, prowadzący do zerwania zbrojenia po- 
przecznego. Zerwanie prętów w kolejnych rzędach przejawiało się uskokami na wykresie zależności obciążanie - przemieszczenie, widocznymi na rys. 10. Towarzyszyły temu także charakterystyczne trzaski, słyszalne w trakcie badania. Zniszczony styk modelu $\mathrm{M}-8 / 43.8 \mathrm{z}$ widocznym zerwanym prętem poprzecznym pokazano na rys. $11 \mathrm{~b}$.

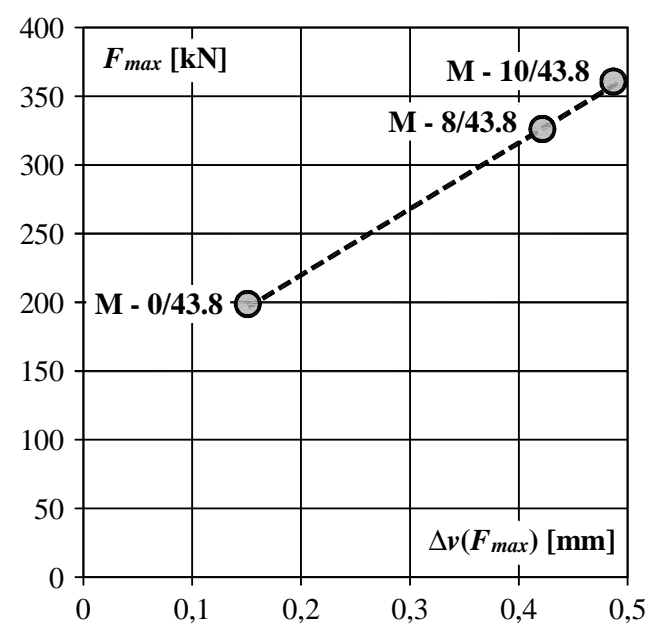

Rys. 9. Przemieszczenia pionowe krawędzi rejestrowane przy maksymalnym obciążeniu

Fig. 9. Vertical displacements between edges of the interface at the ultimate load

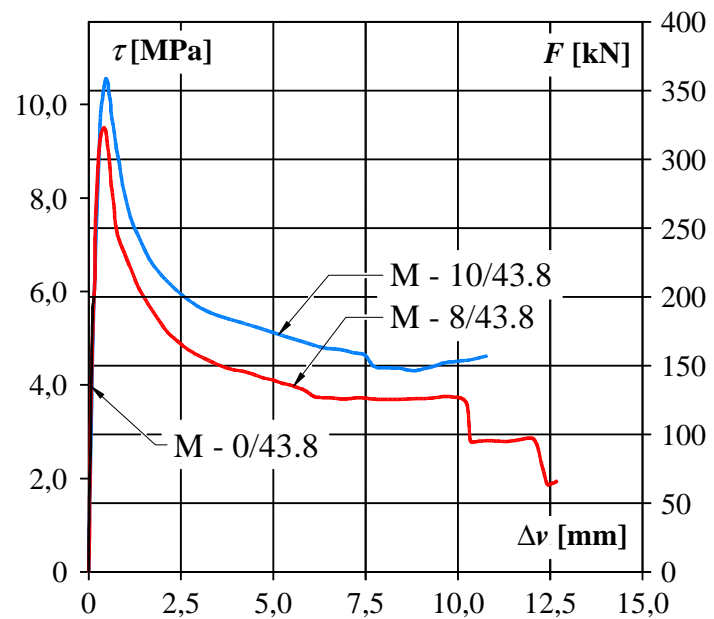

Rys. 10. Przemieszczenie krawędzi styków modeli wynikające z obciążenia

Fig. 10. Displacements between edges of the interfaces resulted from loading of specimen 
Zwiększenie ilości zbrojenia modelu $\mathrm{M}-10 / 43.8 \mathrm{z} \rho_{s}=0,59$ do $0,92 \%$ umożliwiło uzyskanie większej nośności jednak nie wpłynęło na zachowanie modelu w dalszej części badania. Krzywe opisujące zależność obciążenie - deformacja modeli ze stykami zbrojnymi mają bardzo zbliżony charakter. Krzywa opisująca model M - 10/43.8 jest w zasadzie translacją krzywej, charakteryzującej deformacje elementu $\mathrm{M}-8 / 43.8$, o wartość wynikającą z różnicy nośności obu styków. Po przekroczeniu obciążenia maksymalnego elementu M - 10/43.8 obserwowano spadek siły - początkowo wyraźny, w dalszej części badania mniej intensywny czemu towarzyszyło jednak znaczne wzajemne przemieszczanie obu krawędzi styku. Charakter krzywej pozwala przypuszczać, iż przy obciążeniu równym około $150 \mathrm{kN}$ ( 40\% maksymalnego) doszło do uplastycznienia zbrojenia poprzecznego. Ze względu na szerokość szczeliny modelu nie udało się wywołać na tyle znacznych przemieszczeń, by doprowadzić do zerwania zbrojenia styku (jak miało to miejsce w przypadku modelu $\mathrm{M}$-8/43.8). Na rysun$\mathrm{ku} 11 \mathrm{c}$ widoczne jest natomiast przegięte zbrojenie poprzeczne (kinking effect).

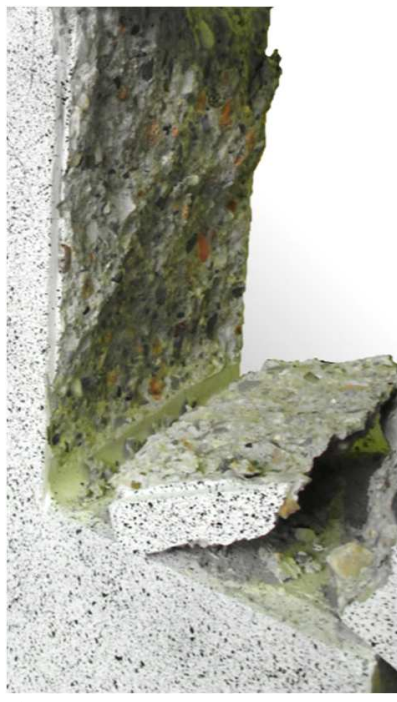

a)

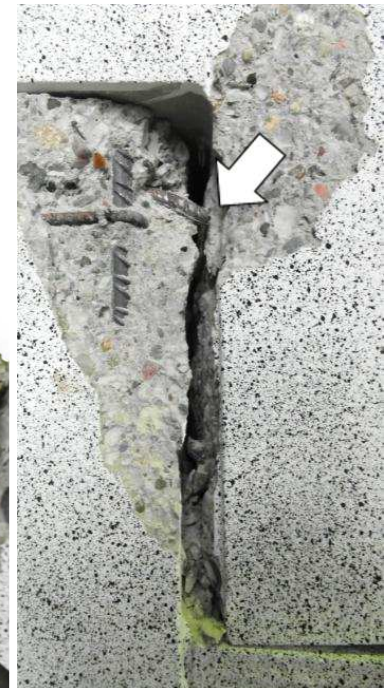

b)

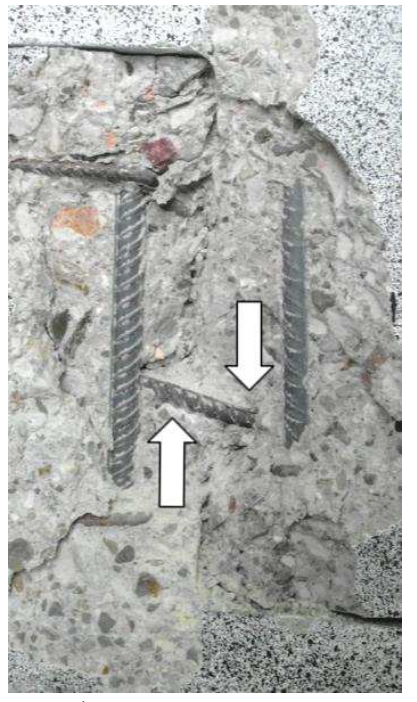

c)

Rys. 11. Badane modele po zniszczeniu: a) $\mathrm{M}-0 / 43.8$, b) $\mathrm{M}-8 / 43.8$, c) $\mathrm{M}-10 / 43.8$

Fig. 11. Test specimens after failure: a) $\mathrm{M}-0 / 43.8$, b) $\mathrm{M}-8 / 43.8$, c) $\mathrm{M}-10 / 43.8$

\section{Nośność modeli w świetle procedur normowych}

Obowiązujące procedury normowe zostały opracowane w odniesieniu do styku betonów układanych w różnym czasie. Jest to przypadek znacznie bardziej niekorzystny od rozważanego $\mathrm{w}$ prezentowanych badaniach. Wobec różnego wieku obu betonów należy oczekiwać także różnic w ich skurczu, co może prowadzić do zarysowania betonu uzupełniającego. W przypadku pełnego zmonoli- 
tyzowania należało oczekiwać także większych sił adhezji. Analiza wyników badań w świetle procedur normowych miała pokazać, na ile mogą być one zachowawcze w odniesieniu do styków w pełni monolitycznych.

Zarówno Eurokod 2 [3] jak i Model Code 2010 [2] uzależniają graniczne naprężenia $v_{R d, i} \mathrm{~W}$ styku pomiędzy betonami układanymi $\mathrm{w}$ różnym czasie od trzech składników: sił adhezji $\tau_{c}$, zazębiania kruszywa $\tau_{a}$ oraz efektu dyblowania $\tau_{d}$. Pierwsza z procedur zakłada superpozycję wspomnianych efektów, przy czym ich wielkość uzależnia się od rodzaju powierzchni (jej szorstkości):

$$
v_{R, i}=c \cdot f_{c t}+\mu \cdot \sigma_{n}+\rho_{s} \cdot f_{y}(\mu \sin \alpha+\cos \alpha) \leq 0,5 v \cdot f_{c}
$$

gdzie: $c$ - współczynnik wyrażający wpływ sił adhezji,

$f_{c t}$ - wytrzymałość betonu na rozciąganie,

$f_{c}$ - wytrzymałość betonu na ściskanie,

$\mu$ - współczynnik tarcia,

$\sigma_{n}$ - naprężenia działające prostopadle do płaszczyzny styku,

$f_{y}$ - granica plastyczności zbrojenia poprzecznego,

$\rho_{s}$ - stopień zbrojenia przecinającego styku,

$\alpha$ - kąt nachylenia zbrojenia względem płaszczyzny styku,

$v$ - współczynnik redukujący wytrzymałość betonu zarysowanego.

Badania eksperymentalne Randla i Wicke [5], dotyczące zbrojonych styków betonów układanych w różnym czasie, wykazały iż utrata sił adhezji następuje bardzo szybko, przy niewielkich przemieszczeniach krawędzi $(\Delta v \leq 0,05 \mathrm{~mm})$. Niemożliwe jest wówczas jeszcze osiągnięcie pełnej nośności zbrojenia poprzecznego. Wykorzystanie nośności wynikającej z efektów zazębiania kruszywa a w szczególności dyblowania wymaga znacznie większych deformacji, dochodzących do około $15 \div 25 \mathrm{~mm}$. Obserwacje te zostały uwzględnione na etapie formułowania procedury zawartej w Model Code 2010 [2]. Z tego względu wyróżniono tam dwa przypadki, formułując różne zależności opisujące nośność styków niezbrojonych i zbrojonych. W pierwszym przypadku jest ona zależna wyłącznie od sił adhezji i tarcia:

$$
v_{R, i}=c_{a} \cdot f_{c t}+\mu \cdot \sigma_{n} \leq v \cdot f_{c}
$$

gdzie: $c_{a}$ - współczynnik wyrażający wpływ sił adhezji,

$f_{c t}$ - wytrzymałość betonu na rozciąganie,

$f_{c}$ - wytrzymałość betonu na ściskanie,

$\mu$ - współczynnik tarcia,

$\sigma_{n}$ - naprężenia działające prostopadle do płaszczyzny styku,

$v$ - współczynnik redukujący wytrzymałość betonu zarysowanego. 
Jeżeli w styku zastosowano zbrojenie poprzeczne, zaś jego ilość jest większa od minimalnej $\left(\rho_{s} \geq 0,05 \%\right)$, wówczas nośność zależy wyłącznie od sił tarcia, efektów zazębiania kruszywa i dyblowania, przy czym ich udział jest zależny od szorstkości powierzchni:

$$
v_{R, i}=c_{r} \cdot \sqrt[3]{f_{c}}+\mu \cdot \sigma_{n}+\kappa_{1} \cdot \rho_{s} \cdot f_{y}(\mu \sin \alpha+\cos \alpha)+\kappa_{2} \cdot \rho_{s} \cdot \sqrt{f_{y} \cdot f_{c}} \leq v \cdot \beta_{c} \cdot f_{c}
$$

gdzie: $c_{r}$ - współczynnik wyrażający wpływ efektu zazębiania kruszywa,

$f_{y}$ - granica plastyczności zbrojenia poprzecznego,

$\rho_{\mathrm{s}}$ - stopień zbrojenia przecinającego styku,

$\alpha$ - kąt nachylenia zbrojenia względem płaszczyzny styku,

$\kappa_{1}$ - współczynnik uwzględniający udział zbrojenia w krępowaniu styku (,siły zszywające”),

$\kappa_{2}$ - współczynnik uwzględniający efektywność zbrojenia w efekcie dyblowania,

$\beta_{c}$ - współczynnik redukujący wytrzymałość krzyżulca ściskanego,

$v$ - współczynnik redukujący wytrzymałość betonu zarysowanego.

Na rysunku 12 pokazano teoretyczne i eksperymentalne nośności modeli badawczych $\mathrm{w}$ funkcji stopnia zbrojenia styku $\rho_{s}$. Widać wyraźnie, iż procedury normowe opisane zależnościami $(1) \div(3)$ są bardzo zachowawcze w odniesieniu do styków w pełni zmonolityzowanych. W obliczeniach założono styk „,bardzo szorstki”, przyjmując największe, dopuszczalne przez procedury normowe wartości współczynników $c$ i $\mu$ ( $c=0,5$ i $\mu=0,9$ według Eurokodu 2 [3] oraz $c_{a}=0,5, c_{r}=0,2$ i $\mu=1,0$ według Model Code 2010 [2]). Teoretyczne nośności elementu ze stykiem niezbrojonym były jednakowe, co wynikało z identycznego opisu naprężeń $v_{R d, i}$ według [2] oraz [3]. W przypadku elementów ze stykiem zbrojonym obserwuje się istotne różnice, dochodzące do 45\%. Większe wartości otrzymano stosując procedurę Eurokodu 2 [3], co wynikało w głównej mierze z pozostawienia współczynnika $c=0,50$ wobec jego ograniczenia do 0,20 w przypadku procedury Model Code 2010 [2]. Układ punktów reprezentujących wyniki badań i obliczeń ma zbliżony charakter. Widoczna jest jednak wyraźna różnica pomiędzy wartościami rzeczywistymi i teoretycznymi. Nośność modelu M - 0/43.8 była ponad 3,5 - krotnie większa od ustalonej na drodze obliczeń. W przypadku elementów ze stykami zbrojonymi różnice były mniejsze, nadal wynosiły jednak około $70 \div 110 \%$ oraz $130 \div 200 \%$ odpowiednio w przypadku Eurokodu 2 [3] i Model Code 2010 [2]. 


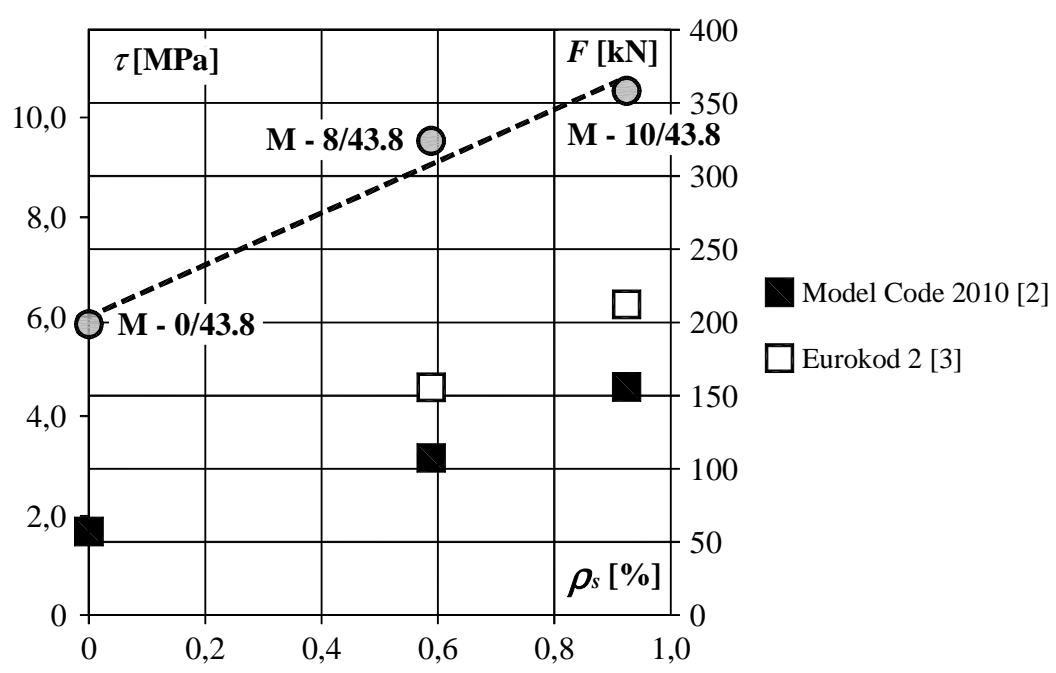

Rys. 12. Porównanie nośności eksperymentalnych i teoretycznych w funkcji stopnia zbrojenia styku $\rho_{s}$

Fig. 12. Comparison between actual and theoretical carrying capacities dependent on interface reinforcement ratio $\rho_{s}$

Na podstawie otrzymanych rezultatów można stwierdzić, iż w odniesieniu do połączeń w pełni zmonolityzowanych wpływ sił adhezji jest znacznie większy niż wynikałoby to z zaleceń normowych. Autorzy postanowień [2] mieli świadomość, iż adhezja stanowi własność zależną silnie od cech betonu, a zatem może się ona cechować znaczną niepewnością (w zależności od zastosowanego kruszywa a także sposobu przygotowania powierzchni). Z tego względu zalecili zastosowanie współczynnika bezpieczeństwa $\gamma_{a d h}=2,0$, który został uwzględniony $\mathrm{w}$ wartości współczynnika $c_{r}$. Przyjmując wartość nominalną $c_{r}=0,40$, otrzymano by nośności zbliżone do ustalonych zgodnie z regułami Eurokodu 2. Należy jednak zaznaczyć, iż dopiero wprowadzenie współczynnika $c=1,75$, pozwoliłoby właściwie opisać wyniki prezentowanych badań. Świadczy to, iż w styku w pełni monolitycznym mogą występować znacznie silniejsze siły adhezji od uzyskiwanych w przypadku styków roboczych, gdy beton układany jest w różnym czasie.

\section{Podsumowanie}

Przeprowadzone badania rozpoznawcze pokazały przydatność urządzenia do pomiarów optycznych ARAMIS do analizy mechanizmów zachodzących w elementach żelbetowych poddanych przecinaniu. Na podstawie zarejestrowanych obrazów oszacowano przemieszczenia krawędzi styków, przy których dochodzi do zerwania wiązań adhezyjnych. Możliwe było również zarejestrowanie pełnej charakterystyki obciążenie - deformacja, uwzględniającej zerwanie zbro- 
jenia styku modelu M - 8/43.8 w końcowej fazie badania. Analiza porównawcza pokazała, iż obowiązujące procedury normowe [2] oraz [3] opisują bardzo zachowawczo nośność styku w pełni monolitycznego. Rzeczywiste nośności były nawet 3,5 - krotnie większe od wartości ustalonych na drodze obliczeń. Przyczyny tego stanu rzeczy należy upatrywać w silnych wiązaniach adhezyjnych, które nie są redukowane m.in. przez zarysowanie wywołane różnicami skurczu betonu (jak ma to miejsce w przypadku betonów układanych w różnym czasie).

\section{Literatura}

[1] ACI 318-14 Building Code Requirements for Structural Concrete (ACI 318-14) Commentary on Building Code Requirements, American Concrete Institute, Farmington Hills (2015).

[2] Ajdukiewicz A.: Pre-norma Konstrukcji Betonowych fib Model Code 2010 (tłumaczenie polskie), Stowarzyszenie Producentów Cementu, Kraków, 2014.

[3] PN-EN 1992-1-1 Eurokod 2 - Projektowanie konstrukcji z betonu - Część 1-1: Reguły ogólne i reguły dla budynków, Polski Komitet Normalizacyjny, Warszawa 2008.

[4] Randl, N.: Design recommendations for interface shear transfer in fib Model Code 2010. Structural Concrete, 2013, 14.

[5] Randl, N. and Wicke, M.: Schubübertragung zwischen Alt- und Neubeton. Experimentelle Untersuchungen, theoretischer Hintergrund und Bemessungsansatz. Beton- und Stahlbetonbau, 2000, 95: 461-473.

[6] Urban T., Krawczyk Ł., Gołdyn M.: Badania eksperymentalne wzmacniania bardzo krótkich wsporników żelbetowych, Czasopismo Inżynierii Lądowej, Środowiska i Architektury - Journal of Civil Engineering, Environment And Architecture, JCEEA, t. XXXIII, z. 63 (1/I/16), styczeń-marzec 2016, s. 297-306, DOI: 10.7862/rb.2016.35.

\section{CONSIDERATIONS ABOUT CARRYING CAPACITY OF ELEMENTS SUBJECTED TO SHEAR CUTTING}

\section{S u m m a r y}

The paper presents the issue of carrying capacity of interface between two concrete casting at the same time. The author's experimental investigations concerning specimens with and without shear reinforcement are presented and discussed. Comparison of experimental and theoretical carrying capacity shows that provisions of Eurocode 2 and Model Code 2010 may lead to underestimation of the ultimate shear stresses in the interface between concretes casting at the same time. Use of the optical measurement system ARAMIS enables the analysis of the deformation and determination of the tested specimens and limits displacement between edges of the interface.

Keywords: shear cutting, concrete - concrete interface, shear stresses, aggregate interlock, dowel action, digital image correlation

Przestano do redakcji: 20.05.2017 r.

Przyjęto do druku: 01.09.2017 r. 